\title{
Comparison of Tomato (Lycopersiconlycopersicum Mill) Varieties to Field Insect Pest Infestations.
}

\author{
DEGRI $^{1}$, M.M. and SANI ${ }^{2}$, A.A. \\ ${ }^{1}$ Department of Agronomy, Faculty of Agriculture, Federal University Kashere, PMB 0182, Gombe, Gombe State, \\ Nigeria \\ ${ }^{2}$ Department of Crop Protection, Faculty of Agriculture, University of Maiduguri, PMB 1069 Maiduguri, Nigeria
}

\begin{abstract}
Tomato crop is widely cultivated in Nigeria. It is prone to heavy infestation by several insect pest species which limit its production. Field experiments were conducted at Gombe State Agricultural Development trial farm, Kwadon, Gombe State in 2012 and 2013 rainy seasons. The study was laid out in a randomized complete block design with four improved tomato varieties and one local variety as treatments replicated four times. Different insect pest species were counted and recorded, plant height, mean number of branches, fruits, mean number of holes, damaged and undamaged fruits were recorded. The results indicated that improved tomato varieties Roma VFN, UTC, Leventis, and Ronita (TOM) were less susceptible to insect pest species infestations while local tomato variety was more susceptible to the pests. Improved tomato varieties used for the study had less insect pest species, produced taller plants, more branches and fruits compared to the local variety. The result further showed that improved tomato varieties were less susceptible to Helicoverpaarmigera damage, hence the lower mean number of holes, damaged fruits and higher undamaged fruits compared to the local tomato variety which had higher mean number of holes, damaged fruits and lower undamaged fruits per plant. The use of improved varieties by poor resource tomato farmers will increase tomato production in Nigeria. Tomato farmers in the study area should be advised to adopt the use of improved tomato varieties for cultivation.
\end{abstract}

Keywords: comparison, susceptibility, tomato variety, insect pest, infestation.

\section{I.INTRODUCTION}

Tomato (Lycopersiconlycopersicun Mill) belongs to the family Solanaceae. It is the second most important vegetable crop in the world after potatoes ( Gerald and Frank, 2005, Schippers , 2000). It is the most commercially grown vegetable in Africa (Schppers, 2000). Tomato is grown mostly in northern Nigeria. Although its cultivation is ecologically restricted due to its temperature and humidity requirements tomato continue to gain popularity because of its high demand and revenue return.tomato production in Nigeria is constrained by a complex of insect pests which include whitefly, Bemisiatabaci; aphids, Aphis sp.; leafhoppers, Empoasca spp.; flower thrips, Thripstabaci; fruitworm, Helicoverpaarmigera and nematode, Meloidogyne incognita (Schuster, 1977a).

The management of tomato insect pests is very crucial to sustainable production of the crop. The readily available method of controlling tomato insect pests is the application of insecticides. Chemical control practices for insect pests fall short in most cases lead to the emergence of resistant strains and the destruction of beneficial organisms Schuster, 1977b). The most important negative effects of the use of insecticides are contamination of the fruits, water sources and environment. One most alternative to the use of insecticides is planting of resistant varieties of tomato which will limit the use of these chemical insecticides ( Baidoo and Mochiah, 2014) variation in insect pest susceptibility has long been noted continues to be found in existing vegetable varieties including tomatoes ( Fery and Schalk, 1990; Eigenbrode et al.; 1993). This study therefore, compares the potentials of four improved tomato varieties in the management of field insect pests of tomato and how the level of field pests infestations affect yield.

\section{MATERIALS AND METHODS}

\subsection{Experimental Site:}

The study was conducted at Gombe state agricultural development project trial farm Kwadon, Gombe situated on Latitude $1017^{\prime} \mathrm{N}$ and Longitude $1109^{\prime} \mathrm{E}$ with an average temperature of $27-40^{\prime} \mathrm{c}$ and mean rainfall of $560 \mathrm{~mm}$ per annum. The site has sandy loam soil and is well drained. The tomato seeds were obtained from NIHORT Substation, Kano, Nigeria.

\footnotetext{
${ }^{1}$ Corresponding Author: michaelmd4peace@hotmail.com
} 


\subsection{Experimental Procedures, Design And Cultural Practices :}

The experiment was conducted in a randomized complete block design with five treatments replicated four times. The treatments comprised of Roma VFN, UTC, Leventis and Ronita (Tom) and a local variety. Tomato seedlings of the five varieties were raised under shade nursery for 4 weeks at the beginning of the rainy seasons of 2012 and 2013. Prior to seedling transplant, field plots of $4.0 \mathrm{mx} 3.0 \mathrm{~m}$ size with $1.0 \mathrm{~m}$ interspace, $2.0 \mathrm{~m}$ alley and $2.0 \mathrm{~m}$ outside border were cleared, harrowed and ridged. The tomato seedlings were gently uprooted with their roots covered with soil to prevent transplant shock and transplanted at $2.5 \mathrm{~cm}$ deep at a spacing of $60 \mathrm{~cm} \times 60 \mathrm{~cm}$ in their labelled plots. One week after transplanting of the seedlings, failed stands were filled to maintain existing gaps and plant populations. After seedlings establishment, the plots were weeded as at when due and NPK 15:15:15 fertilizer was applied.

The tomato fruits were harvested when the green fruits turned yellow to red which were the sign of ripening.

\subsection{Data Collection:}

Data were collected on insect pestspecies numbers that were found attacking the tomato varieties. Counting and recording of insect pest species attacking the tomato started 1 week after seedlings establishment on each plot from ten randomly selected and tagged plants at weekly intervals.

Data on tomato plant heightwere obtained by measuring the plants from each plot from the ground level to the growing tips using a plastic measuring tape.

Data on number of branches were obtained by counting branches produced by each of the ten randomly selected and tagged plants from each plot.

Tomato fruit worm larval holes were assessed at 7days interval from fruit appearance to crop maturity by counting number of larval holes on fruits from the ten randomly selected and tagged plants in each plot.

Total number of fruits damaged and undamaged were counted, weighed from the same ten randomly selected and tagged planted in each plot. The damaged and undamaged fruits were sorted and weighed separately from each plot. Damaged fruits were characterized by tunnels or holes inside the fruits and entrance or exit holes on the fruits. Undamaged fruits were recognized on the basis the absence of the fruit borer holes or entrance or exit holes.

The harvested fruits were weighed and recorded separately from each plant while the total fruit yield data was obtained from the weight of all the fruits harvested from each plot (damaged plus undamaged fruits).

\subsection{Data Analysis:}

The data collected on insect pest species, plant height, number of branches/plant, number of fruits, larval holes, damaged, undamaged fruits, and fruit yield were subjected to analysis of variance (ANOVA). When significant differences were obtained on the different parameters studied, means separated using least significant difference (LSD) and Duncan multiple range test (DMRT) at 5\% level of probability.

\section{RESULTS AND DISCUSSION}

\subsection{Species Of Tomato Insect Pest Population:}

The result for the different species of tomato insect pests recorded on different tomato varieties is presented on Table 1. Table 1. Susceptibility of different tomato varieties to insect pest species

\begin{tabular}{|l|l|l|l|l|}
\hline Tomato variety & \multicolumn{4}{l|}{ AphisspBemisiatabaciEmpoascaspThripstabaci } \\
\hline Roma VFN & 4.83 & 2.62 & 1.28 & 1.87 \\
\hline UTC & 4.80 & 2.59 & 1.25 & 2.17 \\
\hline Leventis & 3.39 & 2.71 & 1.23 & 2.19 \\
\hline Ronita(Tom) & 3.44 & 3.07 & 1.43 & 1.71 \\
\hline Local & 5.26 & 5.78 & 3.79 & 5.78 \\
\hline LSD $(0.05)$ & 1.23 & 0.89 & 0.97 & 0.99 \\
\hline
\end{tabular}

The result shows that there is significant $(\mathrm{p}<0.05)$ difference among the varieties in terms of insect pest species infestations. The local tomato variety had significantly higher number of insect pest species compared to the other improved varieties. This implies that, the improved tomato varieties used for this study have similar resistant ability 
hence, were less susceptible to these insect pest infestations (Luka et al., 2015, Faizaet al., 2012, Baidoo and Mochiah, 2014)

\subsection{Insect Infestations Effect On Tomato Varieties Performance:}

The result for plant height of tomato varieties as affected by insect pest infestations is presented on table 2 . The result shows that improved tomato varieties (Roma VFN, UTC, Leventis and Ronita) grew higher, produced more branches and had higher mean number of fruits per plant while the local variety had short plants, produced fewer branches and had lower mean number of fruits per plant. There was however, difference among the improved tomato varieties in height, number of branches and fruits but the difference were not statistically significant. This indicates that the improved tomato varieties were not affected by the insect pest infestations, hence the significance growth and performance of the improved varietiesSanford and John, 1994, Faiza, 2012, Schuster, 1977a). This result further indicate that the local tomato variety used for the study was highly susceptible to aphids, whitefly, leafhoppers and flower thrips that were recorded infesting the crops, hence the low plant height, few branches and few number of fruits per plant (Luka et al, 2015). The higher mean number of fruits produced by the improved tomato varieties implies that they are less susceptible to insect pest infestations. The differences in tomato varieties susceptibility to insect pest species can be good enough to be potential economic importance in vegetable production (Stoner and Shelton, 1988).

Table 2.insect infestation s effect on tomato varieties performance

\begin{tabular}{|l|l|l|l|}
\hline Tomato variety & plant height $(\mathrm{cm})$ & No. of branches & No. fruits / plant \\
\hline Roma VFN & 4.25 & 31.41 & 11.20 \\
\hline UTC & 4.10 & 30.06 & 10.52 \\
\hline Leventis & 3.25 & 2755 & 11.09 \\
\hline Ronita(Tom) & 3.13 & 30.01 & 11.14 \\
\hline Local & 1.06 & 13.67 & 5.37 \\
\hline LSD $(0.05)$ & 0.72 & 3.81 & 2.97 \\
\hline
\end{tabular}

\subsection{Effect Of Helicoverpaarmigera Damage On Tomato Varieties:}

The result for the effect of H.armigera damage on tomato varieties had significantly $(\mathrm{P}<0.05)$ lower mean number of holes per plant, lower mean number of damaged fruit but higher number of undamaged fruits compared to the local tomato variety used which had highest mean number of holes/plant, highest mean number of damaged fruits/plant but lower mean number of undamaged fruits/plant. This implies that improved tomato varieties used for the study were less susceptible to H.armigera damage than the local variety which is more susceptible to the pest damage (Degri and Mailafiya, 2013, Schuster, 1977b). Eigenbrodaet al., 1993, Fornazier et al, 1986). The higher mean number of damaged fruits recorded on local tomato variety showed that local tomato variety suffered serious damage from the insect pests. Hence the lowest mean number of undamaged fruits/plant (Schuster, 1977a, Faizaet al., 2012, Degri and Mailafiya, 2013). Less damaged fruits recorded under improved tomato variety means less H.armigera damage to the pest. (Stoner and Shelton, 1988, Fornazieret al., 1986).

Table 3.Effect of Helicoverpaarmigeradamage on tomato varieties

\begin{tabular}{|l|l|l|l|}
\hline Tomato Variety & No. of holes/plant & No.damagedfruits/plant & No.undamagedfruits/plant \\
\hline Roma VFN & 1.32 & 3.01 & 7.17 \\
\hline UTC & 2.46 & 4.13 & 6.36 \\
\hline Leventis & 2.25 & 3.11 & 7.97 \\
\hline Ronita(Tom) & 1.30 & 3.09 & 8.03 \\
\hline Local & 5.76 & 5.11 & 0.19 \\
\hline LSD $(0.05)$ & & & \\
\hline
\end{tabular}

\subsection{Effect Of Tomato Varieties On Fruit Weight And Yield:}

Table 4 show the result for tomato fruit weight and yield. Significant $(\mathrm{P}<0.05)$ difference exist between improved tomato varieties and local tomato variety. Improved tomato varieties recorded higher mean fruit weight and yield while local tomato variety had lower mean fruit weight and yield. The result therefore indicates that improved tomato varieties tolerate insect pest's infestations during their growth stages than local variety. The higher mean fruit weight and yield recorded under improved tomato varieties indicate that the fruits were not seriously damaged by H.armigera (Degri and Mailafiya, 2013) while lower fruit weight and yield recorded under local variety implies 


\section{American Research Journal of Agriculture, Volume 1, Issue 2, April 2015}

ISSN 2378-9018

serious damage by due to its H.armigerasusceptibility to the pest. Therefore, farmers using improved tomato varieties along other pest management measures will have a better yield guarantee than those using local variety.

Table4. Effect of tomato variety on fruit weight and fruit yield

\begin{tabular}{|l|l|l|}
\hline Tomato variety & Mean fruit weight $(\mathrm{g})$ & mean fruit yield $(\mathrm{t} / \mathrm{h})$ \\
\hline Roma VFN & $30.22^{\mathrm{a}}$ & $42.84^{\mathrm{a}}$ \\
\hline UTC & $28.49^{\mathrm{a}}$ & $41.95^{\mathrm{a}}$ \\
\hline Leventis & $28.67^{\mathrm{a}}$ & $42.92^{\mathrm{a}}$ \\
\hline Ronita(Tom) & $29.73^{\mathrm{a}}$ & $43.18^{\mathrm{a}}$ \\
\hline Local & $19.23^{\mathrm{b}}$ & $16.21^{\mathrm{b}}$ \\
\hline
\end{tabular}

\section{CONCLUSION}

All the improved tomato varieties namely Roma VFN, UTC, Leventis and Ronita used in thus study were less susceptible to insect pest infestations. The improved tomato varieties suffered less damage from insect pests than local variety indicating certain level of resistance. The present study found that planting of improved tomato varieties by farmers will increase tomato production in the study area.

\section{REFERENCES}

[1] Baidoo, P.K and Mochiah, M.B. (2014). Varietal susceptible of improved cowpeaVigna

[2] unguiculata (L.)(Walp) cultivars to field and storage pests.Sustainable Agriculture Research 3(2):69-76

[3] Degri, M.M and Mailafiya, D.M. (2013).Potentials of Mitracarpusvillosus (L.)

[4] andBalanitesaegyptiaca(Del.) plant Extracts and Cypermethrin in the management

[5] of tomato fruitworm (HelicoverpaarmigeraHubner). Damage in Maiduguri.International

[6] Journal of Agricultural Research, susceptibility and food sufficiency 1(1):1-6

[7] Degri, M.M and Samaila, A.E (2014). Impact of Intercropping Tomato and Maize

[8] ontne Infestation of Tomato Fruitborer (HelicoverpaarmigeraHubner). Journal of Agricultural and Crop Research 2(8):160164

[9] Eigenbrode, S.D, Trumble, J.J, Carson, W.C, White,K.K (1993). Susceptibility of fresh market tomato

[10] varieties to insect pests in southern California, Insecticides and Acaricides Tests 18:172-173

[11] FaizaSaleh, E.E.;Elamin, M.; ElameenEltoun, M.A. ;Hayder ,A.and Dominique, B.

[12] (2012).Susceptibility of some varieties and breeding lines of tomato to Liriomyzaspp

[13] infestation in Central Sudan. Research Application Summary. Third RU Forum Biennial

[14] Meeting 24-28 September, 2012, Entebbe, Uganda. Pp1685-1690

[15] Fery, R.L. and Schalk, J.M. (1990). Resistance in pepper (Capsicum annum L.) to western

[16] flower thrips ( Franklinellaoccidentalis (Pergande). Hortscience 26:1073-1074

[17] Fornazier, M.J.; Filho, N.D. and Pereira, E.B. (1986). Comparison of tomato cultivars

[18] for resistance to the pinworm.HorticulturaBrasileria 4:26-27

[19] Gerald , B. and Frank, Z. (2005). Vegetable insect pest management. Eds. Rick, F. and Brian, R.F. Wiloughby Ohio, USA Meister Media Worldwide.Pp 124-142

[20] Luka, G.Y.; Abdullahi, G. and Shehu, A. (2015). Differential Susceptibility of some Cowpea

[21] Varieties to Field Infestation by Insect Pests in Mubi Region of Sudan Savannah EcologicalZone of Nigeria.

[22] American Journal of Experimental Agriculture 5(4): 366-373

[23] Sanford, D.E. and John, T.T. (1994). Host plant Resistance to Insects in Integrated Pest Management in Vegetable Crops.Journal of Agricultural Entomology 11(3): 201-224

[24] Schippers, R.R. (2000). African Indigenous Vegetables.An overview of the Cultivated Species. Chatham, UK. Natural Resource Institute, ACP-EU Technical Centre for Agricultural and Rural Cooperation $214 \mathrm{p}$

[25] Schuster, D.J. (1977a). Resistance in tomato Accessions to the tomato pinworm. Journal of Economic Entomology 70:434436

[26] Schuster, D.J. (1977b). Effect of tomato cultivars on insect damage and chemical control.Florida Entomology 60:227-232

[27] Stoner, K.A.and Shelton, A.M.(1988).Influence of Variety on Abundance and within Plant Distribution of onion thrips on cabbage. Journal of Economic Entomology 81:1190-1195 